\title{
The Originals of the Original of Don Quixote: Translation and Pseudotranslation in the Spanish Libros de Caballerías
}

\begin{abstract}
Pseudotranslations and references to fictitious originals are a staple of chivalric literature before Don Quixote. In particular, $75 \%$ of the Spanish libros de caballerias refer to some form of, mostly invented, source text. Despite its ubiquity, there are a range of different strategies in connection with what used to be considered a single motif. There are pseudotranslations from fanciful languages, and texts written by magic chroniclers, but also more or less realistic scenarios of translation from foreign tales or chronicles. Some examples are a consequence of the so-called editorial genre - paratextual conventions facilitated by printers and booksellers. Other cases consciously negotiate a textual status throughout the narrative that is less stable and less homogeneous than might be expected. This article briefly explores the different settings of the romances and points out several cases of ambiguous presentation, asking whether pseudotranslations should be treated differently from so-called authentic translations when considering early modern narrative.
\end{abstract}

Keywords: early modern literature, pseudotranslation, romances of chivalry, Spanish literature

Much has been made of the novelty of Cervantes's playful inclusion of a fictitious Arabic source for the text of Don Quixote (1605) after the narration breaks off in chapter eight of the first part. While Cervantes is unsurpassed in the way he employed paradox, metafiction, and metanarrative tendencies, and in the way he explored the ambiguous relationship between translation and supposed original, the inclusion of a fictitious source in itself was not a particularly new idea. In fact, most Spanish chivalric romances from a span of more than a hundred years, from the last decade of the fifteenth until the early seventeenth century, featured different kinds of allusions to pre-texts, to translation, and to found manuscripts. As a motif or topos, this play with "false translation" was first pointed out some time ago and has been regularly mentioned in textual editions and various papers (Eisenberg 1982; Marín Pina 1994, 2004a; García Rojas 2012). It has been regarded as another expected feature of the libros de caballerías, in keeping with the rather static view of the genre. The recent emphasis on the cultural significance of pseudotranslation as a particular subfield of translation studies (e.g. Apter 2006, 210- 
225; Rizzi 2008; Santoyo 2012; Jenn 2013; Vanacker and Toremans 2016), and the manifold implications of this practice, make it worthwhile to return to this issue. The study of what appeared to be a simple motif needs to be expanded in order to look at the ways individual texts negotiate the complexities of their textual status, which, as will be seen, can range from the merely obligatory indication of a source text to highly metafictional involvement.

It is impossible to include more than an overview of the various earlier traditions of found manuscripts and fictitious source texts in Western literatures (for further discussion, see Syrovy [2020]). Suffice it to say that among the chief influences are the various Troy stories, from the Ephemeris Belli Troiani by Dictys of Crete, supposed to be taken from Punic manuscripts found in a collapsed sepulchre, as stated in the prefatory Epistle (Dictys 1973, 1), to the medieval French Roman de Troie by Benoît de Sainte-Maure and other source texts (see Sanz Julián 2010). On the other hand, there is the partly fictional attribution of the Graal stories to Blaise (the confessor of Merlin's mother); to the poet Robert de Boron; and, in the case of the Tristan en prose, to his supposed relative, Hélis de Boron (Baumgartner 1994). By and large intended seriously in the French tradition, the trope was subverted by ironic references to the chronicler Turpino in Boiardo's and Ariosto's Italian romanzi cavallereschi (Syrovy 2013, 173-189). All of this provides ample context for the motif as it appears in the Spanish romances.

Since there are sixty-seven different printed books that belong to the tradition of the libros de caballerias (in 220 extant editions), it will be necessary to give a general overview of the ways that translations are identified in the textual corpus. ${ }^{1}$ The long-predominant quasi-monolithic view of the romances was underscored by the fact that, even in the sixteenth century, printers and booksellers developed a set of rather uniform design strategies for commercial purposes. This has led to the concept of the género editorial for the Spanish romances (see Lucia Megías [2000] for a detailed analysis). It also means, however, that some inherent differences in purpose (entertainment, education, moral instruction, pro-Christian and anti-Islamic propaganda), as well as differences concerning narrative techniques, have been obscured. In addition, there are several texts based on foreign originals that do not particularly emphasize their sources, so it is perhaps too early to draw definite conclusions about the influence of the marketplace on all

\footnotetext{
1 A full bibliography of the romances is still lacking, and so is a collection of their paratexts. The standard bibliographical resource is Eisenberg and Marín Pina (2000), but they exclude important texts by sometimes arbitrary criteria. A supplement can be found in Lucía Megías and Sales Dasí (2008, 295-308), who cover most texts, including Don Quixote (but not the Libro del Cavallero Zifar); they do, however, overlook a number of known editions.
} 
paratextual aspects of the libros de caballerías. A more feasible strategy is to begin by distinguishing between a number of general tendencies.

First of all, some of the romances purport to be based on earlier texts that were emended or corrected (emendados, corregidos). Such a procedure actually occurred in the first volume of Amadis de Gaula (books 1-4, ${ }^{1} 1508$ ), ${ }^{2}$ written by Garci Rodríguez de Montalvo, for which fragments of an earlier manuscript tradition exist (edited in Lucía Megías [2008]; see also Mérida Jiménez [2013]). Several later texts pretend that they, too, reworked earlier sources. In this, Lisuarte de Grecia (Am. 7, 11514), Amadís de Grecia (Am. 9, 11530), Tristán de Leonís, el Joven (1534), Cristalián de España (1545), and Policisne de Boecia (1602) supposedly took their cue from Montalvo. ${ }^{3}$ The influence of Amadís was immense. Volume five, Las Sergas de Esplandián (1521), probably first published in 1496, and also written by Montalvo, started yet another tradition with its inclusion of a highly complex metafictional set-piece where a manuscript written in Greek by the wise chronicler Helisabad is delivered to the author/narrator by one of the characters, the magician Urganda la Desconocida, and serves as the basis for the whole narrative (see Watier 2016, 145-146). This is signalled, if not on the title page, then at least in the incipit and the explicit of the text ("escritas en griego por la mano de aquel gran maestro Helisabad, que muchos de sus grandes fechos vio y oyó," “corregidas y transladadas"; Montalvo 2003, 115, 826). The apex of the metafictional plot is found in chapters 98 and 99 (Montalvo 2003, 525-550). ${ }^{4}$

The rest of the Amadís cycle only added to the range of possibilities. Ruy Páez de Ribera called Florisando (Am. 6, $\left.{ }^{1} 1510\right)$ a translation from the Italian, but mentioned an original Greek text supposedly translated by one Firalites, a disciple of "el gra[n] Petraca [sic]," in its prologue. The fiction of translation, as suggested by the prologue, served mostly as an excuse for Florisando's new-fashioned style. The ideal humanist scholar Francesco Petrarca (Dotti 2004, 450) was himself identified as the translator into Italian of a Latin version of the Greek source of Felixmarte de Hircania (1556). Needless to say, none of this is factual, and by the 1550s, the proliferation of intermediate versions begins to look decid-

2 Because there are many lost editions, and the discussion about possible dates is a complex matter, superscript numbers indicate the first known edition of a given text unless there is only one.

3 By contrast, the authentically medieval Caballero Zifar ( $\left.{ }^{1} 1512\right)$ is adapted for the new market but presented as an old-fashioned, yet unmodernized text in the prologue (Libro del Caballero Zifar 1983, 460). Curiously, the manuscript of the novel included a different prologue where the text was marked as "trasladada de caldeo en latin e de latin en romance" (70).

4 The prólogo of the first Amadís de Gaula also mentioned a found manuscript in an unspecified foreign language as the basis for part IV of the romance. 
edly tongue-in-cheek. The idea of translating Greek via Italian remained prominent, however. In Juan Díaz's Lisuarte de Grecia $(\mathrm{Am} .8,1526)$, this pattern is apparently only mentioned in the explicit and colophon ("Fue sacado delo Griego \& Toscano en Castellano"; f. ccxx r). The first volume of Florisel de Niquea by Feliciano de Silva (Am. 10, $\left.{ }^{1} 1532\right)$, however, talks of an emendation on the title page ("emendada del estilo antiguo") and mentions a Greek to Latin to Spanish translation at the beginning and end of the text, with some later editions including this information in the colophon as well. In two more Florisel volumes (also known as Rogel de Grecia I-II; ${ }^{1} 1535,{ }^{1} 1551$ ) the pattern is maintained, and the supposed authors are even given names: Galersis is the original Greek historiographer and Falistes (alternatively, Filastes) Campaneo his translator into Latin. In 1551, all of this was included on the title page. The twelfth and final book of Amadís, Silves de la Selva (11546) also included a tale of a found manuscript, much like that of Montalvo's Sergas de Esplandián, yet this time the source was not Greek but Arabic, as detailed in a prologue titled "Inuencion de la presente hystoria." Also from the Arabic (via Italian), but not related to the other romances, is Felix Magno I-II (1549; see prólogo), which, in parts III-IV (1549), once again moved to a metafictional level, with the Arabic chronicler becoming part of the story (Demattè 2001, 8). ${ }^{5}$ The same is true for the rather fanciful Phrygian chronicles ("en frigio lenguaje [...] escritos") that form the basis of Febo el Troyano, a playful text that repeatedly quotes from different invented sources, and at the same time incorporates whole passages from other romances (Martín Romero 2005, xv-xxiii). Importantly, it also clearly situates itself within the Troy tradition, as is the case with many other texts, starting with book 3 of the original Amadís de Gaula (Montalvo 1988, 1018). Other, more far-fetched source languages are Tartar, for Claribalte (1519), which on its title page only says "venido a esta lengua castellana" but explains the provenance of the text in the prologue; and Chaldean, from the "Persiana historia general" in that language (via Italian), for Florindo (1530).

Like Amadís, other cycles, too, avoid a "consensus" regarding the supposed textual origin. The cycle of Palmerín de Olivia started in 1511. The story is supposedly taken from an old Byzantine chronicle (it begins "Hállase en las ystorias de aquella muy famosa cibdad de Costantinopla”; Palmérin 2004, 7), but no translational process is explicitly mentioned. Its direct continuation, the Libro segundo de Palmerín (1512), known as Primaleón, says in its colophon: "Fue trasladado este segundo libro de pal /merin llamado Primaleon, e ansimesmo el pri / mero llama-

5 Johnson (2008) offers some interesting thoughts on what translations from the Arabic might imply in terms of power structures in post-Reconquista Spain. 
do Palmerin, de griego en nue / stro lenguaje castellano" (Primaléon 2004, 1). ${ }^{6}$ This belated claim about the status of the earlier volume seems to have been taken into consideration by the printers of a lost 1516 edition of Palmerin, which, according to the library catalogue of Fernando Colón (1488-1539), said on its title page “traduçida de griego en español” (Eisenberg and Marín Pina 2000, 396). Yet, if this was the case, the idea was not taken up by any of the later editions, none of which specify a translation. Another continuation of the romance remains ambiguous: the dedication letter of the anonymous Platir (1533) avoids any reference to translation when talking about the story ("hallé [...] esta ingeniosa historia," "aver aplicado mi trabajo en la impresión d'esta historia”), but the colophon talks about mistakes that might be found "en la tradución de la historia o buen estillo de dezir en romance" (Platir 1997, 363). The context of the other parts of the story and the classical references in the dedication letter vaguely suggest that this part, too, might have come from a Greek source. Several other volumes are further removed from their origins: the vaguely related Spanish Palmerín de Ingalaterra in two volumes (1547-1548) was an authentic translation of the Portuguese Palmeirim de Inglaterra by Francisco de Moraes, first published around 1543 (Marín Pina 2004b, xii), but says nothing of a translation apart from the fact that it is based on the writings of the "sabio Daliarte del Valle Escuro" ([Moraes] 1908, 189). ${ }^{7}$ The son of Platir, Flortir, accomplished his deeds only in an Italian continuation with apparently no Spanish source or translation.

Sometimes, writers handled the topos in a more realistic way. Clarián de Landanís (1518) stated in its incipit: "Fue sacada de lenguaje alemán en italiano por Faderico de Maguncia, obispo de Lanchano, por mandado del sereníssimo rey Fernando de Nápoles, primero d'este nombre. E traduzida y buelta de italiano en vulgar castellano por Gabriel Velázquez de Castillo” (Clarián de Landanís 2005, 16; cf. also xvii). Although these details backdate the source text by at least twenty-five years, they sound like a fairly reasonable claim. Indeed, they are more

6 There are several variations in the other seven known editions. Most importantly, no indication of a translation is given in the Medina del Campo (1563) and, based on the latter, Lisbon (1566) editions (Eisenberg and Marín Pina 2000, \#1958, \#1959), likely not by oversight but because a dedication letter by the bookseller Benito Boyer emphasizes the role of "historias fingidas" and "fictiones" for teaching by example.

7 Daliarte is a character in the Portuguese original. Interestingly, it is Moraes who in his dedication talks about a fictitious original: "Isto me moueo ver se acharia outra antigualha, que podesse tresladar, pera o q[ue] co[n]uersei Alber de Renes em paris (famoso cronista d[e]ste te[m]po): e[m] cujo poder achey algu[n]as memorias de nações estranhas: \& a[n]trelas ha cronica de Palmeirim dinglaterra filho de do[m] Duardos: tam gastada da antiguidade $d[e]$ seu nacime[n]to, que co[m] assaz trabalho a pude ler: Tresladeya por me parecer que pola afeyçãm [sic] de seu pay se estimaria em toda parte" (Moraes 1567, 1v). 
specific than what authentic translations such as Morgante ( $\left.{ }^{1} 1533\right)$, based on Luigi Pulci's poem, or Renaldos de Montaluan (1523) have to say in their respective incipits: "nuevamente de lengua toscana en castellana traduzido" (Morgante 2010, 15) and "los dos libros [...] llamados en lengua toscana el Enamoramiento del emperador Carlos Magno" (Renaldos 2001, 63). ${ }^{8}$ Nevertheless, the topos was pure invention in the case of Clarián. Moreover, the second volume (1522) by one Álvaro, a physician, avoided all references to translation, and instead emphasized the positive aspects of fictional tales. Two further continuations did employ the translation trope: Floramante de Colonia (1550) says "nueuamente trasladada de Aleman" in the colophon and includes a poem by the translator, and Lidamán de Ganail (11528) states "saca[do] [...] del lenguaje alemán en vulgar castellano" (quoted in Díaz-Toledo 2002, 7). ${ }^{9}$ From the Greek, but also via German, comes Philesbián de Candaria (1542); the prologue of Florando de Inglaterra (1545) says it is from an English source, as do the two parts of Florambel de Lucea (both ${ }^{1} 1532$ ). Finally, while Floriseo (1516) specifies no language for its original (the context might suggest both "Bohemian” and Latin), its continuation, Reimundo de Grecia (1524), turns once more to Italian ("Reymundo de Grecia” 2014, 8).

There is one more trope which cannot be said to add to the credibility of the pseudotranslations. Several romances follow Montalvo in combining the nod to an original source with the mention of a wise magician-chronicler, such as "el sabio Fristón" (Fernandez 1997, xix) in Belianís de Grecia ( ${ }^{1} 1547$; from the Greek, according to the title page and colophon). Fristón all but disappears from parts IIIIV (1547); we only learn that the rather abrupt ending was due to the fact that he lost the rest of his manuscript ("Belianís de Grecia” 2013, 37, 927). Another chronicler is found in Cirongilio de Tracia (1545; from the Greek of Novarco via the Latin of Promusis); and the same is true for the already-mentioned Felixmarte de Hircania. Furthermore, the Latin source for Valerián de Hungria (1540) was supposedly written by the wise Arismenio and given to the author by a Hungarian visitor at Worms (Valerián 2010, 5). Finally, King Artidoro wrote the Greek text of Leandro el Bel ( ${ }^{1} 1563$, title page), the continuation of Lepolemo $\left({ }^{1} 1521\right)$. The earlier romance, however, was not only "co[m]puesta en arabigo por Xarto[n]" (title page) but included a "Prologo del Autor Moro sacado d[e] arauigo en castellano" (f. +ij r), and, in 1548, a further translator's prologue (which might have been on the verso of the

\footnotetext{
8 A continuation of Renaldos, La Trapesonda (1533) drops all references to a source text.

9 I was not able to verify the status of yet another, Libro tercero de don Claria[ $n]$ (Toledo: Juan de Villaquirán, 1524), but the British Library catalogue describes its incomplete copy (C.62.i.13) as "purporting to be a translation from the German" (http://primocat.bl.uk/F?func=direct\&local_base=ITEMV\&doc_number=000710469 [31 January 2019]; see also Eisenberg and Marín Pina 2000, 297).
} 
missing title page in the first edition). ${ }^{10}$ This was perhaps inspired by Amadis de Grecia, which also features a "Prólogo del coronista y gran sabio Alquife" (De Silva 2004, 5). On the other hand, Olivante de Laura (1564) does not seek to reconcile the contradictions of a prologue that tells about the discovery of an old Spanishlanguage manuscript corrected for the present edition, on the one hand, and the bookseller's dedication letter, which speaks of commissioning a translation of a supposed Greek original that he found in France, on the other ("esta dulce historia [...] que entre otros libros antiguos de Francia truxe, y la hize traduzir de lengua Griega en Castellana”; f. A2r).

Other romances, like Lidamor de Escocia (1534), supposedly from the Italian, create a dense referential system of fictitious chronicles (see Sáenz Carbonell 1999, 7-9). This is also the case with Cervantes's two parts of Don Quixote, even though the spurious second part by Avellaneda (1614) only half-heartedly acknowledges the fiction at the beginning of chapter one. Arderique (1517) does not even bother to specify which "le[n]gua estra[n]gera" it is from, but nevertheless puts this phrase on the title page (Arderique 2000,1), and may in fact be based on authentic Catalan sources (Carpenter 2000, ix). In turn, Tirante el Blanco (1511), undoubtedly translated from Catalan, says nothing about this fact, and does not even include the original's reference to a (possibly authentic) English-language source (Hauf 2008, 14, 64). Oliveros de Castilla (1498), which has an authentic French original, additionally emphasizes (like the French version) that it is from a fictitious English chronicle, perhaps in Latin, which is not true. Supposedly from the Latin, too, are Rosián de Castilla (1586, title page) and the Espejo de Príncipes y caballeros, specifically part I (1555; incipit, prologue, colophon), ${ }^{11}$ while part II (1580) talks of translation in the explicit, but does not identify a source language. The third part (1588) instead adds a prologue about a discovered manuscript, a source that is presented to the author/narrator as a bilingual Greek and Latin text.

This situation leaves us with the following numbers: from a total of sixty-seven romances, only nine do not mention any kind of source text (such as Polindo, 1526), and a further eight purport to be reworked older texts in Spanish. The rest, fifty romances in total, or $75 \%$, mention translations of some kind, whether they are real or invented, actual or pseudotranslations. Not all of them, needless to say, make

10 A handwritten copy does replace the title page, including the woodcut, but there is no trace of the second prologue.

11 Occasionally (I, 16, 24), Assyrian chronicles are also mentioned as sources for the text. 
use of this construct in the course of narration. This overview also takes into account some still more complicated (but comparatively well-researched) cases not mentioned so far, like adaptations of the Tristan matter (Tristán de Leonis, 1501; Tristán el Jóven, 1534) and the Graal stories (El baladro del Sabio Merlín, ${ }^{11498 ; ~ L a ~}$ Demanda del sancto Grial, $\left.{ }^{1} 1515\right)$, which all have different strategies to refer to partly authentic sources. This is true also for texts from Italian sources: Guarino Mezquino ( $\left.{ }^{1} 1512\right)$ acknowledges its direct source text; Morgante was based on Pulci's poem, and Baldo (1542) in part on Teofilo Filengo's. With the Espejo de cavallerias, the situation is ambiguous, in that the first two parts (1525-1527) are based on Boiardo's Orlando innamorato, and a third, Roselao de Grecia (1550) continues to refer to (this time fictional) Italian pre-texts.

Either way, it needs to be emphasized that none of these books are in any sense literal translations. In fact, the argument is that there are a number of transformative translational processes, be it the prosification of a long epic poem that changes its message and style (see Gómez Montero 1989, 2002), the combination of different source texts, or, indeed, the fictionalization of translating, all of which have tangible consequences. Paratexts usually determine our way of reading, so even minor indications may have a decisive influence on the reader's perception of a text. If all translation may be considered a "re-contextualization" of "de-contextualized" originals that usually comes with changes and modifications that are not incidental but lie at the root of the transfer process (Rössner and Italiano 2012), this is especially true for the early modern period. It is very rare to have as many examples of similar yet different texts within a single genre as we do with the libros de caballerias. Their variations are well suited to clarifying the workings of early modern narrative. In other words: while it sometimes suffices to treat the references in question as a topos, in the majority of cases they open up a range of consequences for the way texts can be read. In all instances, the books also need to be contextualized within the wider tradition of translation in Spain and elsewhere (Pym 2000; Cartagena 2009; Alvar 2010). On these aspects, more careful studies will have to be carried out, but the present overview should serve as a first step toward a differentiation that is very promising for the further study of the $l i$ bros de caballerías and early modern narrative as a whole.

\section{Works cited}

Alvar, Carlos. Traducciones y traductores: Materiales para una historia de la traducción en Castilla durante la Edad Media. Alcalá de Henares: Centro de Estudios Cervantinos, 2010. Apter, Emily. The Translation Zone: A New Comparative Literature. Princeton and Oxford: Princeton University Press, 2006. 
Arderique (Valencia, Juan Viñao, 1517). Ed. Dorothy Molloy Carpenter. Alcalá de Henares: Centro de Estudios Cervantinos, 2000.

Baumgartner, Emmanuèle. "Les Techniques narratives dans le roman en prose." De l'histoire de Troie au livre du Graal: Le temps, le récit (XIIe-XIIle siècles). By Baumgartner. Orléans: Paradigme, 1994. 93-116.

Belianís = Libro primero del valeroso [...] Principe do[n] Belanio. [Burgos]: [Muñoz] 1547.

“Belianís de Grecia (Tercera y Quarta Parte): Edición y estudio.” Ed. Laura Gallego García. Doctoral thesis. Universitat de València, 2013. http://roderic.uv.es/handle/10550/27852 (30 March 2018).

Carpenter, Dorothy Molloy. “Introducción.” Arderique (Valencia, Juan Viñao, 1517). Ed. Carpenter. Alcalá de Henares: Centro de Estudios Cervantinos, 2000. vii-xli.

Cartagena, Nelson. La contribución de España a la teoría de la traducción: Introducción al estudio y antología de textos de los siglos XIV y XV. Madrid: Iberoamericana; Frankfurt am Main: Vervuert, 2009.

Clarián de Landanís (Libro I). Ed. Antonio Joaquín Gonzáles Gonzalo. Alcalá de Henares: Centro de Estudios Cervantinos, 2005.

Demattè, Claudia. Félix Magno (Libros III-IV): Guía de lectura. Alcalá de Henares: Centro de Estudios Cervantinos, 2001.

De Silva, Feliciano. Amadís de Grecia. Ed. Ana Carmen Bueno Serrano and Carmen Laspuertas Sarvisé. Alcalá de Henares: Centro de Estudios Cervantinos, 2004.

Díaz, Juan. Lisuarte de Grecia = El octauo libro de Amadis [...] Lisuarte. Seville: Jacobo Cromberger, 1526. http://bdh-rd.bne.es/viewer.vm?id=0000037677\&page=1 (30 March 2018).

Díaz-Toledo, Aurelio Vargas. Lidamán de Ganail: Guía de lectura. Alcalá de Henares: Centro de Estudios Cervantinos, 2002.

Dictys Cretensis. Ephemeridos Belli Troiani libri. Ed. Werner Eisenhut. Leipzig: Teubner, 1973.

Dotti, Ugo. Vita di Petrarca. Bari: Laterza, 2004.

Eisenberg, Daniel. "The Pseudo-Historicity of the Romances of Chivalry." Romances of Chivalry in the Spanish Golden Age. By Eisenberg. New York: Juan de la Cuesta, 1982. 119-129.

Eisenberg, Daniel, and María Carmen Marín Pina. Bibliografía de los libros de caballerías castelanos. Zaragoza: Prensas Universitarias, 2000. http://www.cervantesvirtual.com/obra/ bibliografia-de-los-libros-de-caballeria-castellanos/ (30 March 2018).

Fernandez, Jeronimo. Hystoria del magnanimo [...] cauallero don Belianis de Grecia. Libro primero. Ed. Lilia E. F. de Orduna. Kassel: Reichenberger, 1997.

García Rojas, Axayácatl Campos. "Variaciones en centro y periferia sobre el manuscrito encontrado y la falsa traducción en los libros de caballerías castellanos." Tirant 15 (2012): 47-60.

Gómez-Montero, Javier. "Orlando, il cavaliere casto? Wandlungen eines erotischen Motivs im Orlando Innamorato und in seiner spanischen Prosa-Übersetzung, dem Espejo de cavallerías." Ritterepik der Renaissance. Ed. Klaus W. Hempfer. Stuttgart: Steiner, 1989. 333-352.

Gómez-Montero, Javier. “Una poética de la re-escritura para los libros de caballerías." Libros de caballerías. Ed. Eva Belén Carro Carbajal. Salamanca: SEMYR, 2002.123-133.

Hauf, Albert. "Nota introductòria." Tirant lo Blanch: Text original, València, 1490. By Joanot Martorell. Ed. Albert Hauf. Valencia: Tirant lo Blanch, 2008. 9-67.

Jenn, Ronald. La pseudo-traduction, de Cervantès à Mark Twain. Louvain-la-Neuve: Peeters, 2013. Johnson, Carroll B. "Phantom Pre-Texts and Fictional Authors: Sidi Hamid Benengeli, Don Quijote and the Metafictional Conventions of Chivalric Romances." Cervantes: Bulletin of the Cervantes Society of America 27.1 (2007). 179-199. 
Leandro el Bel. Libro segundo del esforçado cauallero de la Cruz [...]. [Seville]: [Pérez], n.d. http://digital.onb.ac.at/OnbViewer/viewer.faces?doc=ABO_\%2BZ175247704 (31 January 2019).

Lepolemo $=$ Chronica de Lepolemo [...]. Valencia: Juan Jofre (a cuesta de Juan de Molina), 1521. http://cataleg.bnc.cat/record=b1558117 S13*cat (30 March 2018).

Libro del Caballero Zifar. Ed. Cristina González. Madrid: Cátedra, 1983.

Lucía Megías, José Manuel. Imprenta y Libros de Caballerías. Madrid: Ollero \& Ramos, 2000.

Lucía Megías, José Manuel. “Edición de los fragmentos conservados del Amadís de Gaula medieval: The Bancroft Library: University of California, Berkeley, UCB 115.” Amadís de Gaula 1508: Quinientos Años de Libros de Caballerías. Madrid: Biblioteca nacional de España, 2008. 80-92.

Lucía Megías, José Manuel, and Emilio José Sales Dasí. Libros de caballerías castellanos (siglos XVI-XVII). Madrid: Laberinto, 2008.

Marín Pina, María Carmen. "El tópico de la falsa traducción en los libros de caballerías españoles.” Actas del III Congreso de la Asosiación Hispánica de Literatura Medieval. Ed. María Isabel Toro Pascua. Salamanca: Biblioteca Española del Siglo XV, 1994. 541-548.

Marín Pina, María Carmen. “Motivos y tópicos caballerescos.” Miguel de Cervantes: Don Quijote de la Mancha: Volumen complementario. Ed. Francisco Rico. Barcelona: Galaxía Gutenberg 2004a. 896-938.

Marín Pina, María Carmen. “Introducción.” Palmerín de Olivia. Ed. Giuseppe Di Stefano. Alcalá de Henares: Centro de Estudios Cervantinos, 2004b. vii-xxxvii.

Martín Romero, José Julio. “Introducción.” Febo el Troyano de Esteban Corbera. Ed. Martín Romero. Alcalá de Henares: Centro de Estudios Cervantinos, 2005. vii-xxxiii.

Mérida Jiménez, Rafael M. "Las ejemplares historias fingidas de Montalvo." Transmisión y difusión de la literatura caballeresca: Doce estudios de recepción cultural hispánica (siglos XIII-XVII). By Mérida Jiménez. Lleida: Edicions de la Universitat de Lleida, 2013. 133-162.

Montalvo, Garci Rodríguez de. Amadís de Gaula. Ed. Juan Manuel Cacho Blecua. Madrid: Cátedra, 1988.

Montalvo, Garci Rodríguez de. Sergas de Esplandián. Ed. Carlos Sainz de la Maza. Madrid: Castalia, 2003.

[Moraes, Francisco de]. Cronica do famoso \& muito esforçado caualleiro Palmeirim Dinglaterra [...]. [Évora: André de Burgos, 1567]. Ed. Aurelio Vargas Díaz-Toledo. https://www.univer sodealmourol.com/edicoes/pi-i-ii-evora-andre-burgos-1567 (30 March 2018).

[Moraes, Francisco de]. "Palmerín de Inglaterra: 2a parte (1548)." Libros de Caballerías: Segunda parte. Ed. Adolfo Bonilla de San Martín. Madrid: Bailly, 1908. 187-374.

Morgante: Libro I de Jerónimo de Aunés. Ed. Marta Haro Cortes. Alcalá de Henares: Centro de Estudios Cervantinos, 2010.

Olivante de Laura. Barcelona: Claudio Bornat, 1564. http://bdh-rd.bne.es/viewer.vm? id=0000149352\&page $=1$ (30 March 2018).

Ortúñez de Calahorra, Diego. Espejo de príncipes y cavalleros [El cavallero del Febo]. Vol. 1. Ed. Daniel Eisenberg. Madrid: Espasa-Calpe 1975.

Palmerín de Olivia. Ed. Giuseppe Di Stefano. Alcalá de Henares: Centro de Estudios Cervantinos, 2004.

Platir (Valladolid, Nicolás Tierri, 1533). Ed. María Carmen Marín Pina. Alcalá de Henares: Centro de Estudios Cervantinos, 1997.

Primaleón = Libro segundo de Palmerin que trata [...] de Primaleon. Ed. Lilia Elda Ferrario de Orduna et al. Kassel: Reichenberger, 2004. 
Pym, Anthony. Negotiating the Frontier: Translators and Intercultures in Hispanic History. Manchester: St. Jerome, 2000.

Renaldos = Libro del noble y esforçado \& inuencible cauallero Renaldos de Montaluan: Critical edition. Ed. Ivy A. Corfis. New York: Hispanic Seminary of Medieval Studies, 2001.

"Reymundo de Grecia." Ed. Ivy A. Corfis. Tirant 17 (2014): 5-200.

Rizzi, Andrea. "When a Text Is Both a Pseudotranslation and a Translation: The Enlightening Case of Matteo Maria Boiardo (1441-1494)." Beyond Descriptive Translation Studies: Investigations in Homage to Gideon Toury. Ed. Miriam Shlesinger, Daniel Simeoni, and Anthony Pym. Amsterdam and Philadelphia: Benjamins 2008. 153-162.

Rössner, Michael, and Federico Italiano. "Translatio/n: An Introduction.” Translatio/n: Narration, Media and the Staging of Differences. Ed. Italiano and Rössner. Bielefeld: Transcript, 2012. 9-16.

Sáenz Carbonell, Jorge Francisco. Lidamor de Escocia [...]: Guía de lectura. Alcalá de Henares: Centro de Estudios Cervantinos, 1999.

Santoyo, Julio César. "Seudotraducciones: Pre-textos \& pretextos de la falsificación." Mundus vult decipi: Estudios interdisciplinares sobre falsificación textual y literaria. Ed. Javier Martínez. Madrid: Ed. Clásicas 2012. 355-366.

Sanz Julián, María. "De la llíada a Ein hübsche Histori: Panorámica de la materia troyana en Europa.” Troianalexandrina 10 (2010): 35-70.

Syrovy, Daniel. Tilting at Tradition: Problems of Genre in the Novels of Miguel de Cervantes and Charles Sorel. Amsterdam and New York: Rodopi, 2013.

Syrovy, Daniel. "Translation, Transmission, Irony: Benoît de Sainte-Maure and the Trope of the Fictional Source Text in Western Literature before Cervantes." Taking Stock - Twenty-Five Years of Comparative Literary Research. Ed. Norbert Bachleitner, Achim Hölter, and John A. McCarthy. Leiden and Boston: Brill 2020. 447-492.

Valerián de Hungría de Dionís Clemente. Ed. Jesús Duce García. Alcalá de Henares: Centro de Estudios Cervantinos, 2010.

Vanacker, Beatrijs, and Tom Toremans. "Pseudotranslation and Metafictionality." Interférences littéraires/Literaire interferenties 19 (2016): 25-38.

Watier, Louis. “'La mode était alors que ces sortes d'ouvrages ne devaient pas être originaux ....' La traduction fictive: motifs d'un topos romanesque." Interférences littéraires/Literaire interferenties 19 (2016): 139-154.

Daniel Syrovy studied Comparative Literature at the University of Vienna and wrote his doctoral dissertation on Miguel de Cervantes and Charles Sorel. He has recently spent several years researching the history of Habsburg book censorship between 1750 and 1848, but has now returned once again to early modern studies. 
